\title{
5-Aminosalicylic acid inhibits the impaired epithelial barrier function induced by gamma interferon
}

\author{
M C Di Paolo, M N Merrett, B Crotty, D P Jewell
}

\begin{abstract}
Gamma interferon (IFN $\gamma$ ) impairs epithelial barrier function and induces HLADR expression on colonic cancer cell lines. Salicylates have been shown to reduce IFN $\gamma$ induced HLA-DR expression. The effect of 5-aminosalicylic acid (5-ASA) on IFN $\gamma$ induced changes in transepithelial resistance and permeability was investigated in HT29 clone 19A and Caco 2 monolayers. Monolayers were incubated with different concentrations of IFN $\gamma(100,500$, 1000 , and $3000 \mathrm{U} / \mathrm{ml}$ ) and 5-ASA. IFN $\gamma$ induced class II expression in a time and dose dependent manner in HT29:19A but not Caco 2 cells. HT29:19A monolayers incubated with both IFN $\gamma$ and 5-ASA showed lower HLA-DR expression compared with monolayers incubated with IFN $\gamma$ alone. Electrical resistance and ${ }^{14} \mathrm{C}-$ mannitol flux across HT29:19A monolayers were significantly changed by IFN $\gamma$. Addition of both IFN $\gamma$ and 5-ASA to the basolateral surface of the monolayers significantly reduced paracellular permeability compared with addition of IFN $\gamma$ alone. These data show that IFN $\gamma$ is able to induce HLA-DR expression and to impair the barrier function of HT29:19A monolayers, and that 5-ASA reduces IFN $\gamma$ induced HLA-DR expression and inhibits the effects of IFN $\gamma$ on epithelial barrier function.

(Gut 1996; 38: 115-119)
\end{abstract}

Keywords: interferon $\gamma, 5$-aminosalicylic acid epithelial barrier function.

Normal colonic epithelium does not express HLA class II antigens except when adjacent to lymphoid follicles. ${ }^{12}$ There is considerable HLA-DR expression in many inflammatory diseases of the colon, however, and this correlates with the activation state of lamina propria lymphocytes. ${ }^{3}$ It is probable that induction of HLA-DR expression is mediated by cytokines released by activated cells and, in vitro, it has been shown that gamma interferon (IFN $\gamma$ ) induces both HLA-DR and the adhesion molecule ICAM-1 on colonic epithelial cell lines. ${ }^{4-8}$ Epithelial cells expressing class II molecules stimulate intraepithelial lymphocytes and may present antigens to the underlying mucosal immune system. ${ }^{910}$ 5Aminosalicylic acid (5-ASA) has been shown to competitively inhibit the binding of IFN $\gamma$ to its receptor on a colonic cancer cell line (HT29) and thus inhibit the induction of class II molecules. ${ }^{6-11}$

IFN $\gamma$ has also been shown to increase permeability across epithelial cell monolayers (which may permit increased exposure of the mucosal immune system to luminal antigens), to reduce epithelial chloride secretion, and to induce expression of HLA class I and secretory component. ${ }^{51213}$ These findings have led to the proposal that cytokines such as IFN $\gamma$ may stimulate colonocytes to undergo a transformation from their resting defensive epithelial role to an activated state capable of immune accessory function. ${ }^{1314}$ Activation of the mucosal immune system is a feature of ulcerative colitis and Crohn's disease. Inhibition of these processes may be the mechanism of action of 5-ASA.

The aim of this study was to determine the effects of IFN $\gamma$ and 5-ASA on permeability across epithelial cell monolayers and on the induction of class II and ICAM-1.

\section{Methods}

\section{Cell lines}

Two cell lines, Caco2 and HT29:19A, were studied. Both grow in monolayers that develop a high transepithelial resistance. The $\mathrm{Caco} 2$ colonic carcinoma cell line was obtained from the European Collection of Animal Cell Cultures (ECACC, Porton Down, Salisbury, Wilts, UK) and grown at $37^{\circ} \mathrm{C}$ in 25 and 75 $\mathrm{cm}^{2}$ tissue culture flasks (Sterilin, Feltham, UK) in minimum essential medium (Gibco, Paisley, UK) supplemented with $20 \%$ heat inactivated fetal bovine serum (Flow Laboratories, Irvine, UK) and 1\% non-essential amino acids (Sigma, Poole, UK). The HT29 clone 19A was kindly provided by Dr Christian Laboisse (INSERM 239 Paris) and grown at $37^{\circ} \mathrm{C}$ in $25 \mathrm{~cm}^{2}$ tissue culture flasks (Sterilin, Feltham, UK) in Dulbecco's modified eagle medium (DMEM) with $4500 \mathrm{mg} / 1$ glucose (without sodium pyruvate), supplemented with $10 \%$ heat inactivated fetal bovine serum (Flow Laboratories, Irvine, UK). This clone consists of well differentiated, polarised cells. It has been selected by incubating the parent cell line (HT29) in culture medium with sodium butyrate. ${ }^{15}$

\section{IFNy}

Recombinant IFNy was purchased from Genzyme (Cambridge, MA, USA) $\left(1 \times 10^{6}\right.$ $\mathrm{U} / \mathrm{ml}$, approximately $40 \mu \mathrm{g} / \mathrm{ml}$ ). Its specific 
activity was approximately $2.5 \times 10^{7} \mathrm{U} / \mathrm{mg}$. On arrival, it was diluted $1: 10$ in culture medium and aliquoted (100 000/250 000 units per cryovial). IFN $\gamma$ aliquots were stored at $-70^{\circ} \mathrm{C}$ until use.

\section{5- $A S A$}

5-ASA (Sigma, Poole, UK) was dissolved in $0.2 \mathrm{M} \mathrm{NaOH}$, diluted 1:10 in DMEM, and then brought to $\mathrm{pH} 7 \cdot 4$ by adding $\mathrm{HCl} 0 \cdot 1 \mathrm{M}$. A solution of $10 \mathrm{mM}$, the luminal concentration during oral intake of 5-ASA, was added to the apical side of the monolayers. ${ }^{16}$ A solution of $50 \mu \mathrm{M}$, the maximum serum concentration during oral 5-ASA treatment, was added to the basolateral side. ${ }^{17}$

\section{Cell culture}

Caco2 cells were detached from the flasks using a solution of $0.2 \mathrm{mg} / \mathrm{ml}$ trypsin (Worthington Biochemical Corporation, NJ, USA) and $10 \mathrm{mM}$ EDTA in calcium and magnesium free Hanks's buffered salt solution (Flow Laboratories). They were washed in culture medium, then resuspended and counted in $0.01 \%$ trypan blue. HT29:19A cells were rinsed in Dulbecco's phosphate buffered saline (PBS) without calcium and magnesium, and then incubated in a solution of $1 \mathrm{mM}$ EDTA with a few drops of $0.25 \%$ trypsin in Versene $1 / 5000$ for seven minutes at $37^{\circ} \mathrm{C}$. DMEM with $10 \%$ bovine serum was added after the cells had detached to inhibit the action of trypsin.

Cells were seeded into $25 \mathrm{~cm}^{2}$ flasks at a concentration of $1 \times 10^{6}$ cells per flask, in $5 \mathrm{ml}$ of culture medium. The day after seeding, culture medium was changed and IFN $\gamma$ added in different concentrations $(0,100,500$, and $5000 \mathrm{U} / \mathrm{ml}$ ). After 36 hours, culture medium and IFN $\gamma$ were changed.

\section{Flow cytometry}

After a total incubation of 72 hours, cells were detached and two aliquots ( $10^{6}$ cells in each) from each flask were transferred into $5 \mathrm{ml}$ polystyrene tubes and centrifuged at $100 \mathrm{~g}$ for five minutes. The cells were resuspended in $50 \mu \mathrm{l}$ of PBS with $0 \cdot 1 \%$ sodium azide. A phycoerythrin-conjugated murine $\operatorname{IgG}_{2}$ a antibody against human HLA-DR (Becton Dickinson, CA, USA) was added to one of the two tubes, the other being the negative control. Tubes were quickly vortexed and then incubated for 30 minutes at $4^{\circ} \mathrm{C}$ in the dark. Free antibody was removed by rinsing the cells again with PBS/azide, centrifuging at $750 \mathrm{~g}$ for five minutes, and discarding the supernatant. Cells were then fixed in PBS/azide solution with $1 \%$ paraformaldehyde $(0.5 \mathrm{ml})$ and kept in the dark until flow cytometric analysis.

Flow cytometry was performed on a FACScan (Becton Dickinson). The first samples of each experiment were analysed for size (forward light scatter) and granularity (side light scatter) and a homogeneous population of cells was selected. Fluorescence analysis was performed only on this population and the parameters chosen were then used for analysis of all samples in each experiment. Five thousand cells were analysed for red fluorescence. The lower limit of positive fluorescence was defined by the unstained control cells. The percentage of strained cells showing fluorescence above this cut off point was calculated.

\section{Cells in monolayers}

Cell seeding - cells were seeded $\left(0 \cdot 2-0 \cdot 4 \times 10^{6}\right)$ onto collagen coated MillicellCM culture plate inserts (12 mm diameter), which were then placed in 12 well culture plates and incubated at $37^{\circ} \mathrm{C}$ in $5 \%$ carbon dioxide. Culture medium in inserts and wells was changed every 36 hours. The inserts consist of a transparent, low protein binding Biopore membrane, which allows live cells to be assessed by microscopy. Cell viability was also assessed by measuring the release of lactic dehydrogenase into the culture medium. ${ }^{18}$ Cells grow into polarised monolayers with the apical membrane uppermost and the basolateral membrane attached to the collagen coated membrane. 5ASA was added to the apical surface $(10 \mathrm{mM})$ or the basolateral surface $(50 \mu \mathrm{M})$, and IFN $\gamma$, in different concentrations $(0,100,500$, and $3000 \mathrm{U} / \mathrm{ml}$ ), was added to the basolateral surface after the monolayers developed a high electrical resistance.

Electron microscopy - electron microscopy was performed by Dr David Ferguson (John Radcliffe Hospital, Oxford, UK) on monolayers fixed in $4 \%$ glutaraldehyde.

Electrical resistance - transepithelial resistance was measured using a Voltohmmeter (Millicel-ERS, Millipore UK). Monolayers were considered mature when electrical resistance had risen three to five days after seeding for Caco2 cells and 8-10 days after seeding for HT29:19A cells (see Fig 4). Resistance was corrected for resistance of collagen coated inserts without cells.

Mannitol flux - was measured across cell monolayers as a marker of paracellular permeability. ${ }^{12}{ }^{14} \mathrm{C}$-mannitol $(1 \mu \mathrm{Ci})$ was added

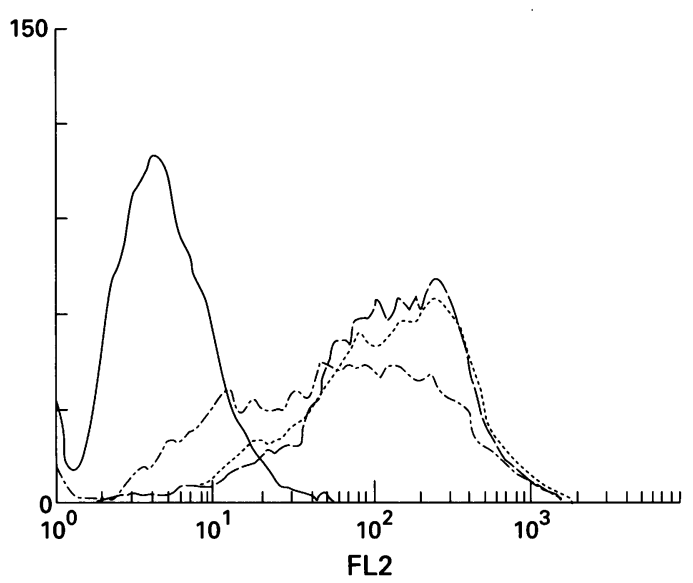

Figure 1: Effect of increasing concentrations of IFN $\gamma$ on $H L A-D R$ expression on HT29:19A cells in suspension. Flow cytometry traces showing the number of cells ( $y$ axis) expressing HLA-DR (measured by fluorescence along the $x$ axis) after incubation with 100, 500, and $5000 \mathrm{U} / \mathrm{ml}$ of IFN $\gamma)$ ( control; - - $100 \mathrm{U} / \mathrm{ml} ; \ldots 500 \mathrm{U} / \mathrm{ml}$; ..... $3000 \mathrm{U} / \mathrm{ml}$ ). 


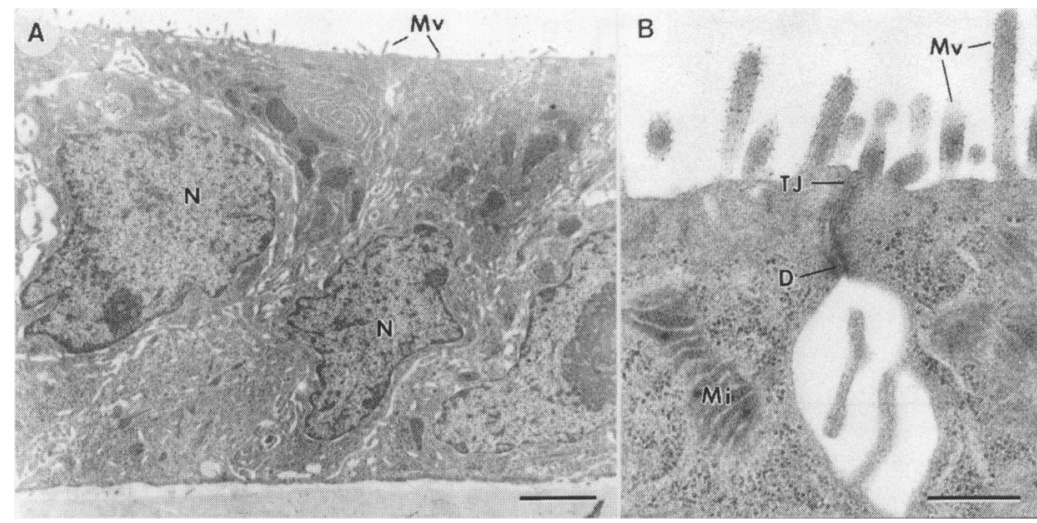

Figure 2: (A) Transmission electron micrograph of a cross section through a filter on which HT29:19A cells were grown showing the monolayer of cuboidal polarised epithelial cells. $N$ : nucleus; Mv: microvilli. Bar is $2 \mu \mathrm{m}$. (B) Details through the apex of two HT29:19A cells showing the well formed junctional complex. D: desmosome; TY: tight junction; Mi:

mitochondrion; Mv: microvilli. Bar is $0.5 \mu \mathrm{m}$.

to the apical surface of monolayers, which had been incubated for 72 hours. Samples $(100 \mu l)$ were collected from the basolateral side of each insert at one, two, and four hours. These samples were added to $400 \mu l$ of distilled water and this was then added to scintillation fluid (Optiphase Safe, LKB Scintillation Products, Loughborough, UK) and counted in an LKB Scintillation counter (LKB Wallac, Uppsala, Sweden). Dpm were converted to $\mathrm{pmol} / \mathrm{cm}^{2} / \mathrm{h} .{ }^{19}$

Immunohistochemistry - monolayers were embedded in OCT (Tissue-Tek, Miles, distributed by $\mathrm{BDH}$, Poole, UK) and stored in liquid nitrogen. Subsequently, monolayers were cut and stained for HLA-DR (CR3-43 antibody, kindly supplied by Dr K Gatter, John Radcliffe Hospital, Oxford, UK) and ICAM-1 (antibody against ICAM-1:18711, British Biotechnology, UK). In each case the second antibody was a peroxidase labelled rabbit antimouse IgG (Dako).

Statistical analysis - of transepithelial resistance and mannitol flux data was performed by analysis of variance.

\section{Results}

Induction of $H L A-D R$

IFN $\gamma$ at all concentrations tested $(100,500$, and $3000 \mathrm{U} / \mathrm{ml}$ ) failed to induce HLA-DR expression on $\mathrm{Caco} 2$ cells $(n=3)$. Expression was induced in HT29:19A cells $(n=3)$,

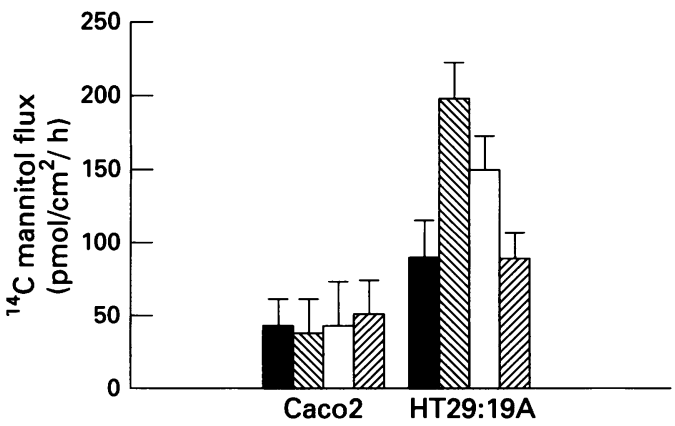

Figure 3: Effect of $500 \mathrm{U} / \mathrm{ml} \mathrm{IFN} \gamma$ and $50 \mu \mathrm{M} 5-A S A$ added to basolateral surface on transepithelial ${ }^{14} C$ mannitol flux across Caco2 and HT29:19A monolayers. Culture $=\square$, IFN $\gamma=\mathbb{W}$. IFN $\gamma$ and 5-ASA $=\square$, 5- $A S A=\mathrm{W}$ however, in a dose and time dependent manner. Virtually all cells incubated with 3000 $\mathrm{U} / \mathrm{ml} \mathrm{IFN} \gamma$ stained for HLA-DR (Fig 1).

\section{Cell monolayers}

For both Caco2 and HT29:19A monolayers, electron microscopy confirmed the polarity of the cells, the presence of tight junctions, and the absence of evidence of cell death after incubation with IFN $\gamma$ with or without 5-ASA for 72 hours (Fig 2). The addition of IFNy with or without 5-ASA did not increase release of lactic dehydrogenase (data not shown).

Caco2 monolayers - IFN $\gamma$ added to the basolateral surface at a concentration of $500 \mathrm{U} / \mathrm{ml}$ did not induce HLA-DR expression in $\mathrm{Caco} 2$ cell monolayers $(n=6)$ confirming results obtained using cell suspensions. IFN $\gamma$ did not affect the barrier function of the monolayers as assessed by transepithelial resistance or mannitol flux (Fig 3).

Monolayers of HT29:19A - cells did not express HLA-DR when cultured in medium alone but there was weak expression of ICAM1. After the addition of IFN $\gamma$ there was strong expression of both HLA-DR and ICAM-1 in a dose and time dependent manner. The expression of both molecules was reduced by addition of $50 \mu \mathrm{M} 5$-ASA to the basolateral surface of the insert.

Electrical resistance across the monolayers increased with time but was reduced by IFN $\gamma$ in a dose dependant fashion (Fig 4). 5-ASA applied to the basolateral surface $(50 \mu \mathrm{M})$ or to the apical surface $(10 \mathrm{mM})$ did not affect the response to IFN $\gamma$.

The Table and Fig 3 show the effect of IFNy and 5-ASA on mannitol flux. Permeability increased with increasing concentrations of IFN $y$ but this effect was significantly inhibited by $50 \mu \mathrm{M}$ 5-ASA added to the basolateral surface. This effect of 5-ASA was not seen when the drug was applied to the apical surface, indeed flux tended to increase (data not shown).

\section{Discussion}

This study has shown differing responses to IFN $\gamma$ in two colonic epithelial cell lines. Caco2, a cell line with many features of small intestinal epithelium, was not affected by IFN $\gamma$ in any of the assay systems. ${ }^{20}$ In contrast, HT29:19A, a well differentiated colonic cell line, showed increased HLA-DR and ICAM-1 expression, increased permeability, and decreased electrical resistance. These effects were dependent on IFN $\gamma$ concentration and length of incubation. Ucer et al have previously shown variable induction of HLA-DR by IFN $\gamma$ on colonic epithelial cell lines. ${ }^{21}$ They found that expression of HLADR was not dependent on the number of IFN $\gamma$ receptors present on each cell, suggesting regulation at a post-membrane level. Our results show that HLA-DR and ICAM-1 can also be induced in high resistance monolayers. 

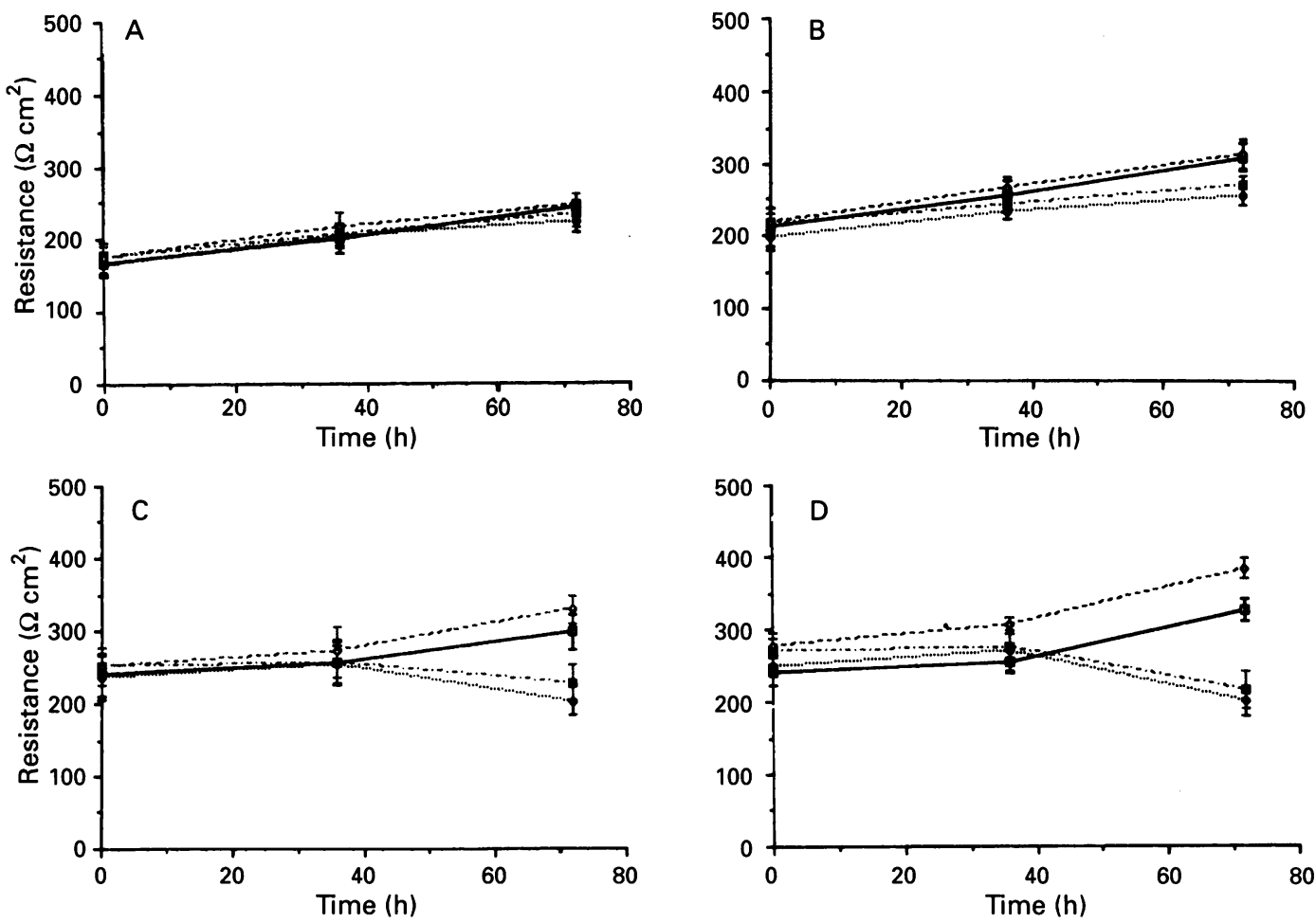

Figure 4: Effect of IFNy or 5-ASA, or both, on transepithelial resistance across monolayers of HT29:19A. Data are expressed as mean (SD) $(n=6)$. Culture medium, ...... IFN $\gamma$, .... IFN $\gamma$ and $50 \mu M$ 5-ASA, . . $50 \mu M$

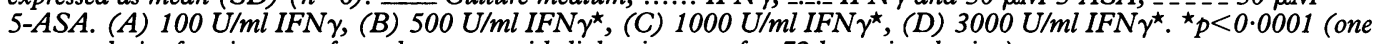
way analysis of variance performed on transepithelial resistance after 72 hours incubation).

Using HT29 cells, we have previously shown that 5-ASA is able to inhibit the induction of HLA-DR by IFN $\gamma{ }^{6}$ This effect is mediated by competitive binding of 5-ASA to the IFN $\gamma$ receptor on the epithelial cell. ${ }^{11}$ The present data confirm this finding in high resistance monolayers. Inhibition was only seen, however, when 5-ASA was applied to the basolateral surface. This is consistent with the finding that receptors for IFN $\gamma$ are confined to the basolateral membrane. ${ }^{22} 23$

There was no effect when 5-ASA was applied to the apical surface at the much higher concentration present in the lumen of patients taking 5-ASA containing compounds. As aminosalicylates are poorly absorbed from the colonic lumen, it is unlikely that 5-ASA added to the apical surface of HT29:19A monolayers can cross to the basolateral surface to inhibit the binding of IFN $\gamma$ to its receptor. Our previous studies showed that the acetylated metabolites of aminosalicylates also impair IFN $\gamma$ binding and HLA-DR induction. ${ }^{611} \mathrm{In}$ contrast with normal colonic epithelium, however, HT-29 cells have a limited capacity to metabolise 5-ASA, and it is probable that there is very little $\mathrm{N}$-acetyl 5-ASA on the basolateral surface of the HT29:19A monolayers. ${ }^{24}$

Transepithelial ${ }^{14} \mathrm{C}$ mannitol flux $\left(\mathrm{pmol} / \mathrm{cm}^{2} / \mathrm{h}\right.$ ) across $H T 29: 19 \mathrm{~A}$ cell monolayers measured during a four hour period after 72 hours incubation with IFN $\gamma$ with or without $50 \mu M$ 5-ASA applied to the basolateral surface. Mean (SD) of six experiments

\begin{tabular}{llccl}
\hline$\gamma I F N$ concentrations & Culture medium alone & IFN $\gamma$ & IFN $\gamma+5-$ ASA & 5-ASA alone \\
\hline $100 \mathrm{U} / \mathrm{ml}$ & $53(13)$ & $71(21)$ & $59(5)$ & $65(7)$ \\
$500 \mathrm{U} / \mathrm{ml}$ & $89(27)$ & $195(27)$ & $149(23)$ & $86(21)$ \\
$1000 \mathrm{U} / \mathrm{ml}^{\star}$ & $78(16)$ & $234(23)$ & $177(29)$ & $80(10)$ \\
$3000 \mathrm{U} / \mathrm{ml}^{\star}$ & $79(14)$ & $262(43)$ & $213(55)$ & $69(11)$ \\
\hline
\end{tabular}

${ }^{\star} \mathrm{p}<0.0001$ by one way analysis of variance.
The mechanism of action of aminosalicylates in inflammatory bowel disease is not known. Intestinal permeability is increased in patients with inflammatory bowel disease and these findings suggest that 5-ASA could improve the barrier function of the colonic epithelium, thus reducing access of luminal antigens to mucosal immune cells. ${ }^{25}$

Thanks are given to Ms Christine Cullen for her assistance in typing the manuscript, to Mrs Caroline Prince for her help in staining and evaluating cell monolayer sections, and to $\mathrm{Dr}$ staining and evaluating cell monolayer

Some of these data have previously been published in abstract Some of these data have previously been publis
form (Gastroenterology 1993; 104 part II: A243).

1 Selby WS, Janossy G, Mason DY, Jewell DP. Expression of HLA-DR antigens by colonic epithelium in inflammatory HLA-DR antigens by colonic epithelium in inflam

2 Spencer J, Finn T, Isaacson PG. Expression of HLA-DR antigens on epithelium associated with lymphoid tissue in the human gastrointestinal tract. Gut 1986; 27: 153-7.

3 Fais S, Pallone F, Squarcia O, Biancone L, Ricci F, Paoluzzi $\mathrm{P}$, et al. HLA-DR antigens on colonic epithelial cells in inflammatory bowel disease. 1. Relation to the state of activation of lamina propria lymphocytes and to the epithelial expression of other surface markers. Clin Exp Immunol 1987; 68: 605-12.

4 DeMayer E, De Mayer-Giugnard J, eds. Production of IFN-gamma by $T$ cells and modulation of T cells, $B$ cells IFN-gamma by T cells and modulation of T cells, B cells and NK activity by interferons. In: Interferons and other regulatory

5 Sollid LM, Gaudernack G, Markussen G, Kvale D, Brandtzaeg $P$, Thorsby $E$. Induction of various HLA Class II molecules in a human colonic adenocarcinoma cell line. Scand $\mathcal{F}$ Immunol 1987; 25: 175-80.

6 Crotty B, Hoang P, Dalton HR, Jewell DP. Salicylates used in inflammatory bowel disease and colchicine impair interferon- $\gamma$ induced HLA-DR expression. Gut 1992; 33: 59-64.

7 Bloom S, Jewell DP. Induction of adhesion molecules by cytokines (interferon-gamma, interleukin 1, tumour necrosis factor alfa, interleukin 6) on the surface of HT29 and I407. Gut 1991; 32: A1239.

8 Kaiserlian D, Rigal D, Abelo J, Revillard JP. Expression, function and regulation of the intercellular adhesion molfunction and regulation of the intercellular adhesion molecule-1 (ICAM-1) on human intestinal

9 Hoang P, Crotty B, Dalton HR, Jewell DP. Epithelial cells bearing class II molecules stimulate allogeneic human bearing class II molecules stimulate allogeneic human colonic $1089-93$. 
10 Mayer L, Schlein R. Evidence for function of Ia molecules on gut epithelial cells in man. $₹$ Exp Med 1987; 166: on gut $1471-83$.

11 Crotty B, Rosenberg WMC, Aronson JK, Jewell DP. Inhibition of binding of interferon- $\gamma$ to its receptor by salicylates used in inflammatory bowel disease. Gut 1992; 33: 1353-7.

12 Madara JL, Stafford J. Interferon-gamma directly affects barrier function of cultured intestinal epithelial monolayers. $\mathcal{F}$ Clin Invest 1989; 83: 724-7.

13 Colgan SP, Parkos CA, Mathews JB, D'Andrea L, Awtrey CS, Lichtman AH, et al. Interferon- $\gamma$ induces a cell surface phenotype switch on T84 intestinal epithelial cell surface phenotype switch on T84 in
cells. Am ₹ Physiol 1994; 267: C402-10.

14 Perdue MH, McKay DM. Integrative immunophysiology in the intestinal mucosa. Am f Physiol 1994; 267: G151-65.

15 Augeron C, Laboisse CL. Emergency of permanently differentiated cell clones in a human colonic cancer cell line in culture after treatment with sodium butyrate. Cancer Res 1984; 44: 3961-9.

16 Lauritsen K, Hansen J, Ryde M, Rask-Madsen J. Colonic azodisalicylate metabolism determined by in vivo dialysis in healthy volunteers and patients with ulcerative colitis. Gastroenterology 1984; 86: 1496-500.

17 Laursen LS, Stokholm M, Bukhave K, Rask-Madsen J, Lauritsen $K$. Disposition of 5-aminosalicylic acid by olsalazine and three mesalazine preparations in patients with ulcerative colitis: comparison of intraluminal colonic concentrations, serum values, and urinary excretion. Gut 1990; 31: 1271-6.
18 Madara JL, Trier JS. Functional morphology of the mucosa of the small intestine. In: Johnson LR, ed. Physiology of the gastrointestinal tract. New York: Raven Press, 1986: 1209-50.

19 Ellory JC. Flux measurements. Shannon: Elsevier NorthHolland Scientific, 1982.

20 Hidalgo IJ, Raub TJ, Borchardt RT. Characterization of the human colon carcinoma cell line (Caco-2) as a model system for intestinal epithelial permeability Gastroenterology 1989; 96: 736-49.

21 Ucer U, Bartsch H, Scheurich P, Pfizenmaier K. Biological effects of $\gamma$-interferon on human tumour cells: quantity and affinity of cell membrane receptors for IFN $\gamma$ in relation to growth inhibition and induction of HLA-DR expression. Int $f$ Cancer 1985; 36: 103-8.

22 McRoberts JA, Barrett KE. Hormone-regulated ion transport in T84 colonic cells. In: Marlin KS, Valentich JD, eds. Functional epithelial cells in culture. New York: Liss, 1989: 235-65.

23 McRoberts JA, Riley NE. Regulation of T84 cell monolayers permeability by insulin-like growth factors. $\mathrm{Am} \mathcal{F}$ Physiol 1992; 262: C207-13

24 Ireland A, Lowes JR, Jewell DP. Acetylation of 5-aminosalicylic acid (5-ASA) and 4-ASA by the HT29 colonic epithelial cell line. Gastroenterology 1990; 98: colonic epithelial cell line. Gastroenterology 1990; 98:

25 Jenkins RT, Ramage JR, Jones DB. Small bowel and colonic permeability to ${ }^{51} \mathrm{Cr}$-EDTA in patients with active inflammatory bowel disease. Clin Invest Med 1988; 11: 151-5. 